\section{Response to "TAlMale, S.S. \& A.D. Tiple (2013). NEW RECORDS OF DAMSELFLY LESTES THORACICUS LAIDLAW, 1920 (ODONATA: ZYGOPTERA: LESTIDAE) FROM MAHARASHTRA AND MADHYA PRADESH STATES, CENTRAL INDIA" WITH A NOTE ON IDENTIFICATION OF LESTES CONCINNUS HAGEN IN SELYS, 1862 AND $L$. UMBRINUS (SELYS, 1891)}

\section{Shantanu Joshi}

Department of Zoology, St. Xaviers College- Autonomous, Mumbai, Maharashtra 400001, India shantanuvanellus@gmail.com

Lestes thoracicus Laidlaw, 1920 is said to be confined to Orissa, Bengal and Bihar in India according to Fraser (1933). Talmale \& Tiple (2013) in the manuscript New records of damselfly Lestes thoracicus Laidlaw, 1920 (Odonata: Zygoptera: Lestidae) from Maharashtra and Madhya Pradesh states, central India have enumerated characters of Lestes thoracicus which none of the specimens actually exhibit, as follows from their own photos. Identity of their specimens, as well as Indian records of Lestes umbrinus (Selys, 1891), are discussed below.

The species $L$. thoracicus is best described by Asahina (1985: 2-13) "The dorsal side of head darkened but the labrum, anteclypeus, base of mandible and genae whitish. Postclypeus is only darkened at the posterior half. Pterothorax pale bluish olive with two small spots on metepisternum. Wings hyaline with pale brownish venation, pterostigma is remarkable with central black marking surrounded by paler area.

Abdomen mat black dorsally, sides pale bluish olive from 2 to $6^{\text {th }}$ segments, distal segments almost mat black, only the last segment shows some yellowish pattern. Superior appendage largely brownish with distal dark portion. Inferiors extending beyond the subbasal spine of the superior and is furnished with apical brush." Fraser (1933) gives the keys to differentiate the female of $L$. thoracicus as, "The female

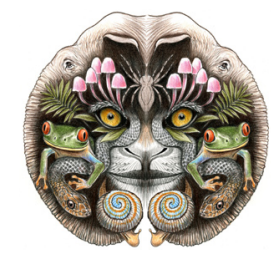

ISSN

Online 0974-7907 Print 0974-7893

\section{OPEN ACCESS} resembles that of Lestes umbrinus (Selys, 1891) rather closely, but distinguished by the head marked with black and by the pterostigma bordered outwardly only with pale brown". The most obvious character in general is a dark middorsal line in last three abdominal segments in both sexes in Lestes concinnus Hagen in Selys, 1862, in $L$. thoracicus the middorsal line is only on the last segment of abdomen accompanied on both sides by two spots. Another striking difference is that the pterostigma is unicolorous with pale brown colour in the specimens in the manuscript, whereas in L. thoracicus it's dark with pale brown outline only.

The anal appendage figures in Talmaly \& Tiple (2013) best match with figures of $L$. concinnus Hagen in Selys, as depicted by Asahina (1985) and Lieftinck (1960). Identification by Talmaly \& Tiple (2013) was based on denticulations of the inner lobe of the cercus, not shown in the L. unbrinus drawing by Fraser (1933). Actually the denticulations are present in both $L$. umbrinus and $L$. concinnus which are closely related, as is well shown by Lietinck (1960). It is not a key to differentiate between these three Lestes species. Another point to note is the tips of the cerci are prominently dark in L. thoracicus.

There used to be uncertainty about the taxonomic status of the species $L$. umbrinus and $L$. concinnus. To quote Fraser (1933), "Laidlaw is of opinion that it is synonymous with $L$. concinnus Selys, form the Philippines and Java; after carefully comparing the description of the species with L. umbrina, I feel inclined

DOI: http://dx.doi.org/10.11609/JoTT.o3546.4125-6

Date of publication: 26 April 2013 (online \& print)

Manuscript details: Ms \# 03546 | Received 02 March 2013

Citation: Joshi, S. (2013). Response to “Talmale, S.S. \& A.D. Tiple (2013). New records of damselfly Lestes thoracicus Laidlaw, 1920 (Odonata: Zygoptera: Lestidae) from Maharashtra and Madhya Pradesh states, central India" with a note on identification of Lestes concinnus Hagen in Selys, 1862 and L. umbrinus (Selys, 1891). Journal of Threatened Taxa 5(7): 4125-4126; http://dx.doi.org/10.11609/JoTT.03546.4125-6

Copyright: (c) Joshi 2013. Creative Commons Attribution 3.0 Unported License. JoTT allows unrestricted use of this article in any medium, reproduction and distribution by providing adequate credit to the authors and the source of publication.

Acknowledgements: My sincere thanks to Oleg Kosterin, without whose help this report would not have been complete. I also thank Noppadon Makbun, Dr. K.A. Subramanian for providing some important information and reviewing the report. 
to share his opinion. If, as he says, Selys had compared the two insects he would probably have hesitated before describing $L$. umbrina as a separate species; the shape of the anal appendages and the markings of segments 8-10 in the female do not differ from L. concinna."

To add to this, M.A. Lieftinck (1934) synonymised these two species and after that these two species were considered synonyms with Lestes concinnus having the preference until 1960; he himself restored the status of these two species in his manuscript 'On the Identity of some little known Southeast Asiatic Odonata in European Museums Described by E. De Selys Longchamps with descriptions of new species' (Lieftinck1960) after studying the types and original descriptions of these two species. He put forth two very important differences between these two species, viz., the shape of pterostigma and anal appendages. The cell of pterostigma is more elongated in Lestes umbrinus than in L. concinnus. In L. umbrinus, the apical portion of the cerci of the male is less abruptly bent than in L. concinnus. Also, the paraprocts are more widely divaricate and are almost concealed when seen from dorsal view in L. umbrinus, whereas in L. concinnus they are invariably exposed and well visible when seen from above. After considering this characters and figures depicted by Lieftinck we can positively reach to a conclusion that the specimens collected by Talmale \& Tiple (2013) are of $L$. concinnus.

L. concinnus has been reported from Andra Pradesh, Gujarat, Maharashtra, Meghalaya, Uttar Pradesh and West Bengal. It is wide spread species in peninsular India and probably co-occur with L. umbrinus (Subramaniam 2013, pers. comm.). From outside Indian borders it has been reported from a wide range of localities.

Lestes umbrinus has been reported from India from: Allahabad (Laidlaw 1920), Nagpur (Laidlaw 1920), Waltair (Laidlaw 1920), Cutch (Fraser 1930, 1933), Duars, West Bengal (Fraser 1933) and is generally considered widespread in India. From outside India it was reported from Myanmar, Thailand, and China. Some (if not nearly all) records of $L$. umbrinus are most likely to be misidentifications of $L$. conccinus. Already the records from China and Thailand are considered to be misidentifications (Hämäläinen \& Pinratana 1999; Wilson \& Xu 2007).

At present, the only reliable record of $L$. umbrinus (Selys, 1861) in the sense by Lieftinck (1960), fixed by his lectotype designation in the heterogenous type series of three specimens by Selys, is the couple represented by the male lectotype itself and the female paralectotype. Noteworthy that even the type locality of this taxon is unclear: Lieftinck (1960: 230-231) provided the following

\begin{tabular}{|l|l|}
\hline Lestes thoracicus & Lestes concinnus \\
\hline $\begin{array}{l}\text { Mid-dorsal line on last two } \\
\text { segments accompanied } \\
\text { by two spots on either } \\
\text { side of the line on the last } \\
\text { segment. }\end{array}$ & $\begin{array}{l}\text { Dark mid-dorsal line on last three } \\
\text { segments. }\end{array}$ \\
\hline $\begin{array}{l}\text { Pterostigma dark with pale } \\
\text { outline. }\end{array}$ & Pterostigma uniformly pale brown. \\
\hline Tip of the cerci dark. & Cerci uniformly coloured. \\
\hline $\begin{array}{l}\text { Dorsum of the head jet } \\
\text { black }\end{array}$ & Dorsum of head dark brown. \\
\hline
\end{tabular}

information about this couple: “... a small label with Atkinon's? writing (which reads as Parishatt, Pashinath, or Pasighat, but not Pamizah). ... The locality "Pamizah" was later supposed by Fraser to be in Bengal, but the writing on the label is undecipherable (There is the place named Pasighat in eastern Pakistan, near Sadiya at the Brahmaputra, north of the Naga Hills).

All this means that the records of $L$. umbrinus also need reviewing and future researchers need to take a note of it. After more research has been done on the current status of $L$. umbrinus and $L$. concinnus then we will be able to further comment on stability of $L$. umbrinus as a different species. Also, with the example of this manuscript the records of $L$. thoracicus from India also need a review

\section{REFERENCES}

Asahina, S. (1985). A list of the Odonata from Thailand. Part VIII Lestidae. Chô Chô 8(8): 2-13.

Fraser, F.C. (1930). Indian dragonflies - XXXV. Journal of the Bombay Natural History Society 34(1): 87-107, figs. 1-4, incl. pl. 1-1.

Fraser, F.C. (1933). The Fauna of British India including Ceylon and Burma. Odonata Vol. I. Taylor and Francis Ltd. London, 423pp.

Hämäläinen, M. \& A. Pinratana (1999). Atlas of the Dragonflies of Thailand. Distribution maps by provinces. Brothers of St. Gabriel in Thailand, Bangkok, 176pp.

Laidlaw, F.F. (1920). A list of the dragonflies recorded from the Indian Empire, with special reference to the collection of the Indian Museum. Part III. The genus Lestes and its allies. Records of Indian Museum 19(4): 145-163, figs. 1-8, incl. pl. 5-5.

Lieftinck, M.A. (1934). An annotated list of the Odonata of Java, with notes on their distribution, habits and life history. Treubia 14: 229256.

Lieftinck, M.A. (1960). On the Identity of some little known Southeast Asiatic Odonata in European Museums Described by E. De Selys Longchamps with descriptions of new species. Memoirs of Society of Entomology of Italy 38: 229-256.

Talmale, S.S. \& A.D. Tiple (2013). New records of damselfly Lestes thoracicus Laidlaw, 1920 (Odonata: Zygoptera: Lestidae) from Maharashtra and Madhya Pradesh states, central India. Journal of Threatened Taxa 5(1): 3552-3555; http://dx.doi.org/10.11609/ JoTT.03264.947

Wilson, K.D.P. \& Z. Xu (2007). Odonata of Guangdong, Hong Kong and Macau, south China, part 1: Zygoptera. International Journal of Odonatology 10: 87-128+pls. I-VIII; http://dx.doi.org/10.1080/1388 7890.2007 .9748292 